LATIP 2021

International Conference on Language and Technology in the Interdisciplinary Paradigm

\title{
THE METAPHORICAL REPRESENTATION OF THE COVID-19 PANDEMIC IN THE TURKISH MEDIA
}

\author{
Inna Onal (a)* \\ *Corresponding author
}

(a) Novosibirsk State Technical University, Prospekt K. Marksa, 20, Novosibirsk, 630073, Russia, onal@corp.nstu.ru

\begin{abstract}
The article examines metaphors used to comment on the coronavirus pandemic in the Turkish media. The study addresses the following issues: (a) conceptual metaphors underlying the expressions and word combinations used in covering different aspects of the pandemic and (2) distribution of metaphors between the identified metaphorical models. The data of the study include metaphorical expressions from the Turkish online resources (news reports, analytical articles and speeches of politicians). The findings reveal that the COVID-19 virus is described in the Turkish media communication as an "enemy", "monster", "disaster" or "examination". The source domain WAR is the most productive for the conceptualization of the coronavirus pandemic as it employs the highest number of linguistic items. The detailed metaphor analysis shows that the use of metaphors in the media serves a two-fold purpose: first, to catch the readers' attention and second, to shape the readers' attitude to the current political situation. The obtained data give insight on the cultural-cognitive model of the pandemic.
\end{abstract}

2357-1330 @ 2021 Published by European Publisher.

Keywords: Coronavisus, cognitive metaphor, mediadiscourse, metaphor, metaphorical representation 


\section{Introduction}

Metaphors traditionally occupy a special place among the linguistic means used to influence the addressee of the message in order to form a certain attitude towards the subject of the message and, thus, participate in creating and reproducing social realities in the discourse. It is known that metaphor is primarily a mental phenomenon, while a metaphorical expression is considered as an "accidental" linguistic form reflecting a cross-domain mapping that underlies it (Lakoff \& Johnson, 1980). It is mapping between a source and a target domain that helps people understand one domain in terms of another. According to Kövecses (2010), mapping is "a set of fixed conceptual correspondences that exist between constituent elements of the source and the target domains" (p. 12). A metaphorical framing, in its turn, is a message comparing some abstract concept to another concept that is more concrete and easier to comprehend. Metaphorical framings are commonly used in media discourse to communicate about urgent social and political issues due to their highly persuasive power.

\section{Problem Statement}

The use of metaphors in communication about the COVID-19 pandemic has been viewed by scholars from different perspectives, such as finding out the most common source domains, comparative analysis of the metaphors used for COVID-19 and other diseases, examining the pragmatic effects of the COVID-19 metaphors and proving a better way to frame the pandemic (Semino, 2021). It seems natural that most of the research has been conducted on the English linguistic data because of its prevalence and availability (e.g., there is an online collection of news articles in English on this topic https://www.english-corpora.org/corona/). The study of metaphorical representation of the pandemic in other languages (including Turkish) seems to be relevant as it may prove the universality of metaphors used in pandemic-related media discourse (as Lakoff and Johnson in 1980 assumed, some metaphors are universal or near-universal) and/ or expose some culture-specific and linguistic variations.

\section{Research Questions}

In the study the following research questions are addressed: 1 . What metaphorical models are used to represent Covid-19 in the Turkish media? 2. Which metaphorical models are more commonly used and why? 3. What effect are the metaphors expected to produce on the recipients?

\section{Purpose of the Study}

The purpose of the study is to identify the main metaphorical models Turkish journalists and politicians employ to represent the coronavirus pandemic. The metaphorical model is understood as the relationship between the conceptual domains existing in the minds of native speakers, in which the system of frames of the source domain serves as the basis for modelling the conceptual system of the target domain. 


\section{Research Methods}

The research material includes articles (news, analytical) in the Turkish media from the following online sources: Milliyet, Birgün, HBR Caldıran, Akşam, TRT Haber, Hurriyet, Habertürk, etc., as well as the texts of the Turkish president's speeches available at the website https://www.tccb.gov.tr/receptayyiperdogan/. The data was selected in accordance with the following criteria: 1) thematic (keywords: koronavirüs/korona, kovid/covid, pandemi); and 2) linguistic (original publications in Turkish were considered). The methodology used in the study combines conceptual metaphor theory (Chudinov, 2003; Kövecses, 2010; Lakoff \& Johnson, 1980; Popova \& Sternin, 2007) and the critical analysis of metaphor which is an integration of corpus linguistics, cognitive linguistics and critical discourse analysis (Charteris-Black, 2004).

When identifying a metaphor in a discourse for subsequent analysis, researchers use either the "top down" or "bottom up" approach. Following the first approach, the researcher tries to find the realization of the concept in the metaphor, while the second approach, on the contrary, assumes the distribution of concepts after extracting the metaphors from the discourse and identifying their metaphorical affiliation. The use of the "top-down" method can be illustrated by the algorithm proposed by Chudinov (2003). It includes the following steps: 1) describing the source domain; 2) defining the target domain; 3) describing the model-specific scenarios; 4) correlating the model with the fragments of the naive language picture of the world that make up this conceptual area, which are understood as frames; 5) creating a set of slots in each frame, which are understood as elements of the situation that specify the frame; 6) analysing the reason for the metaphorical expansion, i.e. why these source domains are used for a new conceptual domain. A similar technique is employed by Popova and Sternin (2007) in the framework of semantic and cognitive analysis. The "bottom up" approach can be illustrated by the Metaphor Identification Procedure developed by the Pragglejaz Group (2007). The MIP procedure is a four-step analysis of lexical units in order to detect the presence of metaphoricity by comparing the basic and contextual meaning of the lexical unit. According to this method, everything that is reproduced in the discourse in a non-basic meaning is a metaphor. As a point of reference for the establishing of basic meanings the most reputable dictionaries of the given language are used.

In the current study both "top down" and "bottom up" approaches have been employed. Thus, there were two stages of the data extraction. At the first stage the articles with the key words 'koronavirüs", "korona", "kovid", “covid", "pandemi" were chosen and examined; then the manual analysis of metaphorical expressions was carried out by assigning semantic tags corresponding to their literal meanings. After the main source domains of metaphors used for the pandemic were identified, I proceeded to the second stage using the "top down" approach described above. (For example, proceeding from the assumption that following the WAR model the virus could be described as ENEMY, there may be SOLDIERS, ARMY, CASUALTIES, people may be WINNING or LOSING the WAR, I continued the search using such combinations of keywords as "koronavirüs" and "mücadele", "koronavirüs" and “düşman”, etc.).

At the next stage of the research the examples of metaphorical expressions were analysed and distributed between the source domains of metaphorical expansion represented by them, among which 
WAR, NATURAL PHENOMENA, and EXAMINATION were highlighted. Then the qualitative and quantitative analysis of the metaphorical expressions referring to the given source domains was performed.

\section{Findings}

The qualitative analysis of the collected data shows that the COVID-19 pandemic in the Turkish media discourse is framed chiefly through the metaphors of war and battle, natural phenomena and examination (Table 1).

Table 1. Source domains for representation of the COVID-19 pandemic

\begin{tabular}{ccc}
\hline Source domain & Frequency & $\%$ \\
\hline War & 89 & $75.4 \%$ \\
Nature & 18 & $15.2 \%$ \\
Education & 11 & $9.3 \%$ \\
\hline
\end{tabular}

\subsection{Pandemic is war (battle)}

A review of studies on the metaphorical representation of the concept "disease" shows that it is the military metaphor that is most in demand for the coverage of this phenomenon (Flusberg et al., 2018; Ribeiro et al., 2018; Semino et al., 2018; Wicke \& Bolognesi, 2020). However, the description of the pandemic in terms of war is currently criticized by scholars and journalists. Thus, Tisdall argues that "the language of the battlefield" arouses fear and anxiety, compromises democracies, splits communities and may even legitimize the use of actual military actions. Semino claims that introducing martial law and/ or warlike powers for the executive in some countries "reveals the potentially fuzzy boundary between the literal and metaphorical status of military references during the pandemic". Nevertheless, it seems that though having a strong negative valence, war metaphors are very productive in pandemic-related discourse, for they are highly conventional, relatively simple and based on the knowledge possessed by everyone. The model may be represented by various correlations between the conceptual domains WAR and PANDEMIC, for example, the virus is an enemy, medical workers are the army (heroes, allies), applying treatment is fighting, medicines and vaccines are weapons, etc.

The examples below contain typical Turkish media expressions used to describe the coronavirus pandemic and its aspects through the metaphor of struggle and battle (PANDEMIC is a WAR).

\subsubsection{The virus is an enemy}

The pandemic is described as a dangerous enemy, a cunning and strong creature; capable of deceiving, inflicting wounds, causing sufferings:

1. Korona gitmiyor, gümbür gümbür geliyor! / Corona does not go away, but rumbles closer! (Antakya Gazetesi); 
2. Koronavirüs: gezegeni tehdit eden düşman / Coronavirus: the enemy that threatens the planet (Aimsad).

It is worth mentioning that the virus "hits a blow" mainly in economic and sports news discourse which may be explained by the fact that blow is quite a conventional metaphor for these types of discourse.

\section{Petkimspor'a koronavirüs darbesi / Coronavirus blow to Petkimspor (TRTSpor).}

Though sometimes used to denote the virus, the word "düşman" ("enemy") is chiefly employed with reference to something used to oppose the virus rather than to the virus itself (see examples 4-6):

4. Koronavirüs düssmanın artık tanıyoruz / Now we know the coronavirus enemy (Sabah).

5. Koronavirüs düşmant: D Vitamini / Coronavirus enemy is vitamin D (Sigorta Dünyası).

6. Ülkemizi ve tüm dünyayı etkisi altına alan corona virüs salgınından korunmak için bir çok yöntem arlyor ve bağışılklı̆̆ güçlendirmek için elimizden geleni yapıyoruz. Diyetisyen Gizem Gençyürek corona virüse düssman sağlığa dost olan besinleri açıkladı. / We are looking for many ways to protect ourselves from the corona virus epidemic that has affected our country and the whole world, and we are doing everything we can to strengthen immunity. Dietitian Gizem Gençyurek explained what nutrients are friendly to health and hostile (lit. "enemy") to the coronavirus (CNN Türk)..

\subsubsection{Virus is a monster}

Alongside with the VIRUS is an ENEMY metaphor comes the metaphor of the VIRUS as a MONSTER. Sometimes it is hard to differentiate between the two, since within both models we employ a similar set of related words: a monster is also supposed to be "fought against", those who "win the battle" with it can be treated as "heroes". However, the image of a MONSTER is usually ascribed threatening features and loaded with extremely negative connotations with the help of the lexemes describing its appearance and behaviour.

1. Kovid-19'u yenen doktor Boyacl: "Beni boğan bir canavarla mücadele ettim" / Doctor Boyact who defeated Kovid-19: "I fought a monster that strangled me" (aa.com.tr).

In the following examples we can see that in the Turkish president's rhetoric the virus acquires the features of a hostile creature:

2. Salgın dünyayı çeşitli sınamalarla baş etmekte zorlandığı bir dönemde yakaladı (R. T. Erdoğan)/ The epidemic caught the world at a time when it was difficult to cope with various tests (R. T. Erdogan).

3. Dünya Koronavirüs salgınının pençesinde kıvranırken biz her biri kendi alanında çı̆̆ır açacak eserlerin yükselişinin sevincini yaşıyoruz (R. T. Erdoğan). / As the world writhes in the grip of the coronavirus epidemic, we experience the joy of the rise of groundbreaking works, each in its own field (R. T. Erdogan). (The first meaning of the lexeme "pençe" is "fingers and nails of the forelimbs of predators"). 


\subsubsection{People are participants of the battle}

Both individuals and groups of people, countries and mankind as a whole appear as participants in the battles, as a result of which they can turn out to be victims, losers or winners:

1. Dünya Koronaya Teslim! Hayatını kaybedenleri sayısı korkunç boyuta ulaştı / The World Yields

to the Corona! The number of people who lost their lives has reached a terrible figure (HBR Caldiran).

2. Koronavirüsü yenen paramedik Ebru'dan kurallara uyun çăgrıst. / A paramedic who has won coronavirus urges to follow the rules (Hürriyet).

3. “Covid-19 salgını ile mücadelemize ilk günkü kararlılık ve gayretimizle devam ediyoruz” (F. Koca). / "We continue our fight against the Covid-19 epidemic with our determination and effort on the first day (F. Koca, saglik.gov.tr).

It should be noted that, despite the use of a militarist metaphor in the Turkish media discourse, both in Turkish news reports and in the speeches of the president of Turkey containing references to the pandemic, the lexemes "savaş" and "muharebe" ("war") are rarely used directly. The leaders of a number of European states have repeatedly declared their being at "war" with the virus. Less emphatic and more conventional expressions "virüsle mücadele", "salgınla mücadele”, "koronada normalleşme” are preferred to "savaş" ("war') and "kazanç" ("victory"). Health workers, in their turn, are not considered "army" or "soldiers" (which is also typical of the traditional military metaphor when describing an epidemic), but can be described as "kahramanlar" ("heroes"):

4. Să̆lıkçıların korona virüs ile mücadelesi belgesel oldu: 'Kahraman Să̆lıkçılar' belgeselinin ilk gösterimi açıkhava salonunda yapıldl. / The fight of medics with the coronavirus became a documentary: the first screening of the documentary 'Heroic Medics' was held in an open-air hall (Habertürk).

5. Korona virüsle savaşta gizli kahraman. I A Secret Hero in the Fight with the Coronavirus (Yeniçağ).

6. “Koronavirüs savaşında kurallara uyarak kahraman olabiliriz" / "We can be heroes by following the rules in the coronavirus war” (E. Altunbaş, Haberturk)

As the above-quoted examples show, it is not only medical workers who can be heroes in the battle with the pandemic, but also citizens who follow the rules (TMM - Temizlik, Maske, Mesafe (“Cleanness, Mask, Distance”)), and even substances that help fight the virus (Omega-3 in Example 5). Thus, the metaphor of war can inspire the population to unite in the fight against the disease.

\subsection{Pandemic is a natural disaster}

The metaphorical model of a PANDEMIC is a NATURAL DISASTER is represented by less numerous examples in pandemic-related discourse which may be due to weaker potential of this model as compared with the WAR model. 
1. Akyazı'da korona patlaması! / Coronavirus outbreak (lit. "explosion") in Akyazi! (Medyabar).

2. Tüm dünya ile bütünüyle beraber ülkemizi de etkileyen koronavirüs salgını dalgalar halinde yaylmaya devam ediyor (R. T. Erdoğan) / The coronavirus epidemic, which affects our country along with the whole world, continues to spread in waves (R. T. Erdogan).

3. Yeni tip koronavirüs (Kovid-19) salgınınin ikinci dalgast Sudan'l öncekinden daha şiddetli vurdu. / The second wave of the outbreak of the new type of coronavirus (Kovid-19) has hit Sudan more severely than before (Şarkul Avsat).

4. "Böyle giderse kı̧̧ döneminde ikinci dalga değil tsunami görürüz"/ "At this rate, we will see a tsunami, not a second wave in winter" (Prof. Dr. K. Aydın, Birgün).

5. "Küçük dalgalar halinde farkl zamanlarda ve farkl yerlerde yeniden yeniden baş gösterecek"। "It [pandemic] will start again at different times and in different places in small waves" (T24).

As the examples demonstrate, the pandemic is mainly represented through the metaphors of TSUNAMI and WAVE. The model is rather handy in talking of the arrival and spreading of the pandemic. According to Jones \& Helmreich (2020), epidemic waves are useful in visualizing and reasoning about COVID-19 data, and also may serve as an instrument for public health management and prediction. On the other hand, unlike an enemy, a wave or tsunami cannot be avoided if you are in its path; the only hope is to get out of its way. As a result, this metaphor may arouse fatalism and decrease people's willingness to take protective measures.

In the rhetoric of the Turkish president, the pandemic is also described as a "disaster", "misfortune" ("musibete", "felaket"), that has befallen mankind:

6. Bu musibete karşı birlikte hareket etmek, birlikte mücadele etmek yerine her ülke adeta kendi slğınağına kaçmaya çalışıyor. / Instead of acting together and fighting together against this calamity, each country is almost trying to escape to its own refuge.

7. Rabbimden bizi ve tüm insanlı̆g bu mübarek gece hürmetine bir an önce koronavirüs musibetinden kurtarmasinı niyaz ediyorum. / I ask my Lord to save us and all the mankind from the scourge of coronavirus as soon as possible in homage to this blessed night.

Thus, within this model, a person appears as a fighter against the natural disaster, and his survival and well-being depend on the victory over it. However, as we can see from the Turkish president's speech extracts, God may help people survive this disaster; therefore people should pray for salvation.

\subsection{Pandemic is an examination}

Finally, an important place in the coverage of the pandemic in media communication is occupied by the metaphorical model THE PANDEMIC IS AN EXAM. A person is assigned the role of a student, who has to take a difficult and important exam:

1. Dünya genelinde etkili olan yeni tip koronavirüs (Covid-19) salgininda ülkeler büyük bir sinavdan geçiyor. / Countries are taking major examination in the outbreak of the new type of coronavirus (Covid-19) effective worldwide (Indyturk).

3. KoronaVirüs Rabbimizden bizlere bir İkaz ml, bir İmtihan mı? / Is Coronavirus a warning to us from our Lord or an Examination? (Net Haber). 
This metaphorical model seems to be more commonly employed by columnists and politicians rather than by news reporters. As well as the NATURAL DISASTER metaphor, this one also seems to help enforce religious unity in the people.

\section{Conclusion}

Conceptual metaphors are based on the existing stereotypical ideas which are most capable of influencing the recipient. The choice of a particular metaphor is influenced by the combination of specific conditions and the context of use. Using a metaphor, the speaker identifies the most significant, in their opinion, characteristics of the object, interprets them, forming an image of the coronavirus in the recipient's mind. Though criticized by some scholars, the military metaphor remains most common in describing the pandemic in many languages including Turkish.

Although the objectives of the study did not include the differentiation of metaphorical models by genres of media discourse, certain regularities were still noted. Thus, the war metaphor is relevant, first of all, for news articles (especially their headlines and leads), as it is expressive and helps attract the attention of recipients and create a certain attitude to the problem; for analytical articles, in turn, the use of the metaphor of examination is characteristic, and in the rhetoric of the president there are all the above metaphorical models. The predominance of the military metaphor on the whole can be explained by the more extensive structure of this metaphorical model, as well as its greater pragmatic potential.

\section{References}

Charteris-Black, J. (2004). Corpus Approaches to Critical Metaphor Analysis. Palgrave Macmillan.

Chudinov, A. P. (2003). Metaphorical Mosaics in the Modern Political Communication. Ural. gos. ped. university.

Flusberg, S. J., Matlock T., \& Thibodeau P. H. (2018). War metaphors in public discourse. Metaphor and Symbol, 33(1), 1-18.

Jones, D. S., \& Helmreich, S. (2020, June 26). The Shape of Epidemics. Boston Review http://bostonreview.net/science-nature/david-s-jones-stefan-helmreich-shape-epidemics

Kövecses, Z. (2010). Metaphor: A practical introduction (2nd edition). Oxford University Press.

Lakoff, G., \& Johnson, M. (1980). Metaphors we live by. The University of Chicago Press.

Popova, Z. D., \& Sternin I. A. (2007). Cognitive Linguistics. AST; Vostok-Zapad.

Pragglejaz Group. (2007). MIP: A method for identifying metaphorically used words in discourse. Metaphor and Symbol, 22, 1-39.

Ribeiro, B., Hartley, S., Nerlich, B., \& Jaspal, R. (2018). Media coverage of the Zika crisis in Brazil: The construction of a "war" frame that masked social and gender inequalities. Social Science \& Medicine, 200, 137-144. https://doi.org/10.1016/j.socscimed.2018.01.023

Semino, E. (2021). "Not Soldiers but Fire-fighters" - Metaphors and Covid-19, Health Communication, 36(1), 50-58. https://doi.org/10.1080/10410236.2020.1844989

Semino, E., Demjén, Z., Hardie, A., Rayson, P., \& Payne, S. (2018). Metaphor, cancer and the end of life: A corpus-based study. Routledge.

Wicke, P., \& Bolognesi, M. (2020). Framing COVID-19: How we conceptualize and discuss the pandemic on Twitter. PloS One, 15(9). https://doi.org/10.1371/journal.pone.0240010 